\title{
ANALISIS TERHADAP KESINAMBUNGAN LEMBAGA PEMBIAYAAN PEDESAAN DALAM MENDUKUNG USAHA MIKRO, KECIL DAN MENENGAH
}

\author{
Khusnul Ashar \\ Fakultas \& Bisnis Ekonomi Universitas Brawijaya
}

\begin{abstract}
The research goal is to find how far the degree of sustainability of rural financial institutions that exist and to identify the variables that determine what operational sustainability yaginstitutions concerned. From the results of statistical tests and the discussion can be summarized as follows: The degree offinancial sustainability for rural finance institutions significantly affected by the variable operating cost and revenue variables which level income has a positive relationship while variable costs have a negative relationship. The influence of variable operating costs are relatively greater than the influence of income variable; Good Rate Revenues and Cost of Operations has a positive relationship and the real magnitude of value of receivables/ loan value; level offinancial sustainability of institutions did not show a clear pattern of relationship with the efficiency (either from the indicator value of loans per staff and per-unit cost of borrowing/Cost per unit of Money Lent); Compared with the indicator Cost per unit of Money Lent, the value of loans per staff show a clearer pattern of relationship with the magnitude of the Average-Performing Asset (the Cost per unit of Money Lent did not show a clear pattern of relationship with the AveragePerforming Asset). Average value addition is dominated by the Performing Asset Value Receivable. It can be concluded that the greater the value of Average Performing Assets, the greater the value of receivables and the more efficient institutions KSP.
\end{abstract}

Keywords: financial institutions, sustainability.

\section{A. LATAR BELAKANG}

Salah satu pendekatan yang digunakan di negara sedang berkembang untuk mengatasi masalah kemiskinan dan pengembangan UKM adalah berupa program-program penyediaan kredit kecil melalui pendirian Lembaga Kredit Mikro. Di Indonesia program kredit mikro bahkan sudah ada sejak zaman penjajahan Belanda dan semakin banyak ragam metode dan nama programnya setelah zaman kemerdekaan (Suharto, 1991; Raviez, 1996; Suyatno dkk, 1999). Alasan yang melatarbelakangi munculnya pendekatan tersebut adalah karena kegagalan lembaga kredit formal untuk mengatasi problem kemiskinan di pedesaan (Huppi dan Feder, 1990; Holt dan Ribe 1991). Alasan lain adalah karena program penyediaan kredit kecil relatif lebih mudah diimplementasikan daripada program pengentasan kemiskinan lain seperti program land-re- 
form (Braverman dan Guasch, 1989). Esensi program kredit mikro bukan hanya semata-mata pada ketersediaan kredit kecil melalui berbagai nama lembaga penyalurnya, tetapi lembaga kredit mikro adalah merupakan piranti pembangunan dalam arti luas (Ledgerwood, 1999). Beberapa program kredit mikro seperti Grameen Bank di Bangladesh, BRI-Unit Desa di Indonesia dan beberapa program koperasi kredit dan pinjaman kelompok di Kamerun, Malaysia dan Korea Selatan telah mencatat keberhasilan karena keunggulan sistem insentif, kontrol dan sistem monitoringnya (Von Pischke, Adams dan Donald 1983; Yaron, 1992; Robinson, 1994; Khandker $\mathrm{dkk}, 1995)$.

Dalam konteks wilayah pedesaan, pada haekatnya LKM merupakan bagian dari Lembaga Pembiayaan Pedesaan yang beroperasi sampai kepelosok-pelosok desa. Lembaga Pembiayaan ini di Indonesia beroperasi dalam bentuk Bank (BPR/BPRS, BRI Unit, BKD) maupun dalam bentuk Non Bank yang formal (Koperasi, LDKP) dan yang non formal (BMT dan lembaga keuangan yang dikelola Lembaga Swadaya Masyarakat dan Yayasan). Sampai dengan tahun 2001, jumlah BPR/BPRS di Indonesia mencapai 2.419 unit, BRI Unit 3.694 unit; BKD 5.345 unit; KSP 1.097 unit; USP 35.218 unit; LDKP 2.272 unit; LSM-KSM-BMT 2.914 unit ( Bank Indonesia, 2002).

Sampai dengan tahun 2000, jumlah kredit yang telah disalurkan oleh BPR/BPRS mencapai 3,6 trilyun rupian; BRI Unit 7,8 trilyun, BKD sebesar 0,16 trilyun; KSP/USP sebesar 0,5 trilyun; LDKP sebesar 0,36 trilyun dan dari BMT-LSM-KSM sebesar 0,05 trilyun rupiah ( BI, 2002).

Dari paparan diatas, tersirat pentingnya keberadaan lembaga pembiayaan pedesaan bagi UMK yang merupakan tumpuan hidup kaum miskin. Namun demikian, pertanyaan yang penting untuk diklarifikasi adalah bagaimanakah kesinambungan hidup lembaga pembiayaan pedesaan itu sendiri.

Penelitian Khandker terhadap Grameen Bank di Bangladesh menyimpulkan bahwa terdapat empat faktor yang saling berkaitan sehubungan dengan kelangsungan hidup dan kinerja lembaga kredit mikro yaitu faktor keuangan, institusi, nasabah dan kondisi ekonomi (Khandker et al, 1995). Secara spesifik berdasarkan hasil penelitian terhadap dua jenis LKM di Indonesia, Kaluge menyimpulkan bahwa kesinambungan hidup lembaga kredit mikro tergantung pada tingkat keuntungan yang dipengaruhi oleh faktor besarnya penerimaan, biaya operasional, tingkat angsuran, besarnya bunga pinjaman dan tingkat efisiensi (Kaluge,2001).

Melihat pentingnya keberadaan lembaga pebiayaan dalam membantu mengatasi masalah kemiskinan dan meningkatkan perekonomian pedesaan, kajian yang khusus menganalisis kelangsungan hidup LKM di pedesaan kabupaten Malang merupakan salah satu upaya akademis yang penting untuk dilakukan. Identifikasi terhadap faktor-faktor yang mempengaruhi kesinambungan lembaga pembiayaan pedesaan tidak hanya bermanfaat praktis bagi pemerintah dan stakeholder lain seperti pihak pemodal dan masyarakat, namun juga akan memberikan kontribusi akademis khususnya di bidang keuangan mikro dan pembangunan kelembagaan desa. 


\section{B. KERANGKA TEORITIS}

\section{Peran Lembaga Pembiayaan Dalam Meningkatkan Kapasitas Kegiatan Ekonomi Berskala Mikro}

Dalam model dasar perekonomian, pendapatan keluarga merupakan fungsi dari aset yang dikuasai, baik berupa sumber daya alam, tenaga kerja, maupun sumber daya modal. Makin besar jumlah dan tingginya mutu aset yang dikuasai suatu keluarga dan makin besarnya pemanfaatan aset-aset tersebut dalam kegiatan produksi, makin besar pula pendapatan yang diperoleh keluarga tersebut. Berdasarkan model ini, pendapatan keluarga miskin dapat ditingkatkan melalui perbaikan jumlah, mutu, dan kesempatan untuk lebih memanfaatkan aset yang dikuasainya. Aset utama keluarga miskin adalah tenaga kerja fisik. Rendahnya pendidikan dan ketrampilan tenaga kerja dari kalangan keluarga miskin menyebabkan, mereka tidak mampu memasuki pasar tenaga kerja formal. Hanya sebagian kecil saja yang terserap pada sektor formal dan itupun hanya bekerja sebagai buruh industri manufaktur dengan memperoleh upah rendah.

Peluang kerja informal yang akrab dengan kehidupan kaum miskin dapat dikategorikan ke dalam dua golongan besar, yakni sebagai buruh yang bekerja pada orang lain, dan mereka yang bekerja mandiri (self employment). Mereka yang bekerja pada orang lain umumnya melakukan pekerjaan sebagai buruh tani atau buruh kasar lainnya; sedangkan mereka yang bekerja mandiri, umumnya melakukan pekerjaan sebagai pedagang kecil yang berjualan sayur, barang bekas (rombengan), atau membuka warung makan kecil, memproduksi dan menjual berbagai kerajinan rumah tangga, beternak unggas, sebagai penjahit dan masih banyak bentuk kegiatan informal lainnya.

Bila dikaji lebih lanjut, bekerja mandiri memiliki nilai-nilai positif lebih banyak daripada bekerja sebagai buruh. Pertama, bekerja mandiri mempunyai peluang lebih besar untuk di kembangkan karena kesempatan kerja untuk menjadi buruh di sektor informal terutama di pedesaan sangat terbatas, seringkali bersifat musiman, dan kebanyakan menghasilkan upah yang rendah dengan tingkat ketergantungan tinggi kepada pihak majikan. Kedua, bekerja mandiri memerlukan pengerahan segala aset yang dikuasai oleh satu keluarga, sehingga produktivitas aset-aset keluarga cenderung lebih tinggi daripada bila keluarga tersebut hanya memanfaatkan tenaga kerjanya sebagai buruh. Ketiga, pekerjaan mandiri memiliki potensi untuk mendorong berkembangnya kesempatan kerja baru bagi anggota keluarga lain yang ada. Makin berkembang usaha itu, makin banyak tenaga kerja disekitarnya dipekerjakan.

Setiap usaha yang potensial untuk dikembangkan memerlukan tambahan dana untuk meningkatkan usahanya. Perolehan kredit yang digunakan secara tepat (jumlah, jenis, waktu, dan tempat) memungkinkan peningkatan penguasaan faktor-faktor produksi dan meningkatkan pendapatan yang diperoleh melalui pengembangan usaha. Makin banyak usaha mandiri ataupun pekerja dari kalangan miskin memperoleh dan memanfaatkan kredit secara tepat, makin besar keuntungan yang dapat diraih, dan pada gilirannya pendapatan keluarga miskin akan meningkat. 
Pengusaha kecil biasanya menghadapi banyak masalah, baik internal maupun eksternal, tetapi pemecahan masalah tersebut ber-tumpu pada satu cara atau beberapa masalah pokok yang krusial. Dalam hal ini masalah modal biasanya menjadi persoalan yang paling krusial diantara masalah-masalah lainnya, dan perlu dipecahkan secara nasional (Rachbini, 1994).

Kebutuhan kredit keluarga miskin mempunyai ciri khas, yakni sulitnya ditarik garis yang tegas antara kebutuhan kredit produksi dan kredit konsumsi. Sebab, bagi mereka pengeluaran untuk keperluan rumah tangga dan pengeluaran untuk usaha merupakan suatu kesatuan yang sulit dibedakan. Menurut Djojohadikusumo (1989), kredit sendiri tidak menjadi penyebab dinamisasi kegiatan ekonomi. Tetapi kredit yang terorganisasi dengan baik memang merupakan suatu persyaratan untuk dinamisasi kegiatan ekonomi. Selama kegiatan ekonomi masyarakat tempat suatu lembaga kredit pedesaan bersifat statis, maka kredit yang diberikan oleh lembaga itu sebagian besar akan bersifat statis pula. Kredit statis adalah kredit yang bertujuan untuk mempertahankan suatu tingkat kesejahteraan. Dengan demikian pemberian kredit kepada masyarakat miskin hanya akan menjadi kredit dinamis yang efektif meningkatkan pendapatan bila disertai dengan upaya membimbing kegiatan ekonomi masyarakat ke arah yang dinamis dan mengaktifkannya.

\section{Perkembangan Pembiayaan Untuk Usaha Kecil}

Kebijakan perbankan untuk meningkatkan pelayanan kredit kepada golongan masyarakat miskin telah banyak dilakukan. Berbagai program kredit usaha kecil, seperti Kredit Investasi Kecil (KCK) dan Kredit Modal Kerja Permanen (KMKP) pada tahun 1974, Kredit Candak Kulak (KCK) dan Kredit Inpres pada tahun 1976, serta beberapa program kredit lainnya telah disalurkan melalui bank-bank umum, BRI dan Koperasi Unit Desa. Pada tahun1988 terbit keputusan Presiden RI Nomor 38 yang mengatur Bank Perkreditan Rakyat (BPR) sebagai istilah resmi untuk lembaga-lembaga perkreditan masyarakat kecil yang telah lama ada seperti Lumbung Desa, Bank Desa, Bank Pasar dan sebagainya. Sedangkan paket kebijaksanaan (Pakjan) 29 Januari 1990 merupakan paket reformasi kredit yang mewajibkan antara lain bank-bank menyalurkan 20\% kreditnya untuk usaka kecil yang dikenal sebagai Kredit Usaha Kecil (KUK) (Suharto, 1991).

Mengamati pelaksanaan Pakjan 1990 tentang keharusan bank menyalurkan minimal 20\% kreditnya dalam bentuk KUK, seperti tidak ada alasan untuk mengatakan bahwa bank belum menyalurkan kredit kepada pengusaha kecil. Sampai tahun1994 secara keseluruhan bank-bank telah menyalurkan KUK tidak kurang dari $26 \%$. Namun banyak pakar masih meragukan apakah penyaluran KUK tersebut telah benar-benar sampai pada pengusaha kecil (Masassya, 1994), terutama mengingat batasan pengusaha kecil menurut kriteria perbankan adalah pengusaha yang memiliki aset sampai 600 juta rupiah.

Dilihat dari proporsi besarnya kredit kecil terhadap seluruh kredit yang tersalur, tampak bahwa penyaluran kredit kecil dapat dikatakan belum menjangkau masyarakat miskin sebagaimana yang diharapkan. Jumlah kredit kecil, termasuk Kredit Pemilikan Rumah (KPR), selama tahun 1974 - 1986 hanya sekitar 5-20 persen dari jumlah kredit perbankan. Kredit yang disalurkan oleh BPR, bentuk bank khusus yang melayani usaha kecil golongan ekonomi lemah atau sektor informal, antara tahun 1974-1986 baru berkisar antara 0,3-13 persen dari seluruh kredit perbankan (Suharto, 1991). Karena batasan pengusaha kecil menurut kriteria perbankan adalah pengusaha 
yang mempunyai aset sampai 600 juta rupiah, maka besar kemungkinan penyaluran kredit kecil yang benar-benar sampai ke masyarakat miskin adalah jauh lebih kecil lagi. Sedangkan di lain pihak berdasarkan data Susenas tahun 1987, dari 9,27 juta perusahaan yang didata 98,5 persen $(9,1$ juta) terdiri dari pengusaha yang tergolong pengusaha sektor informal.

Namun demikian, bila perkembangan masing-masing bentuk perkreditan untuk rakyat kecil diamati secara parsial, beberapa bentuk penyaluran kredit yang telah disesuaikan dengan sifat permasalahan pengusaha kecil menunjukkan perkembangan yang menggembirakan. Kredit Investasi Kecil (KIK) maupun Kredit Modal Kerja Permanen (KMKP), yang pada tahun 1974 posisi nilai realisasinya sebesar 26 miyard rupiah, meningkat menjadi 1,25 trilyun rupiah pada tahun 1983 dan selanjutnya menjadi 2,534 trilyun rupiah (April 1990). Kredit Mini dan Midi, yang ditujukan untuk golongan miskin, seperti petani gurem, buruh tani, pedagang, pengrajin dan nelayan juga menunjukkan perkembangan yang sangat pesat (Rachbini, 1994).

\section{Determinan Kinerja Lembaga Pembiayaan Pedesaan.}

Kinerja lembaga pembiayaan pedesaan bisa dilihat dari dua sisi yaitu sisi pencapaian sasaran (outreach) dan segi kelangsungan hidup lembaga (sustainability). Dari hasil penelitian di Jawa Timur, Zain mengemukakan bahwa terdapat 4 indikator yang bisa digunakan untuk menilai kinerja lembaga kredit mikro yaitu: stabilitas dan kinerja usaha nasabah; pendapatan dan asset anggota binaan; derajat ketergantungan nasabah pada rentenir, dan stabilitas kelangsungan hidup lembaga (Zain, 2001). Dumairy mengemukakan bahwa lembaga kredit mikro yang mempunyai kinerja tinggi adalah lembaga yang jumlah nasabahnya semakin banyak dengan nilai pinjaman yang semakin besar; pelayanannya semakin mudah dijangkau; nilai asetnya semakin besar; nilai tabungan anggota binaan semakin tinggi; dan tingkat pengembalian pinjaman yang tinggi (Dumairy, 1986).

Dari beberapa penelitian, faktor-faktor yang menentukan kinerja dan kelangsungan hidup lembaga kredit mikro telah diidentifikasi. Kajian yang dilakukan oleh Hoff dan Stiglitz menyimpulkan bahwa faktor subsidi, rendahnya tingkat recovery dan erosi portfolio akibat rendahnya tingkat bunga riel telah menurunkan tingkat solvabilitas dan viabilitas banyak lembaga kredit pedesaan (Hoff dan Stiglitz, 1990). Penelitian Khandker dkk. terhadap Grameen Bank di Bangladesh mengemukakan bahwa terdapat empat konsep yang saling berkaitan sehubungan dengan kelangsungan hidup dan kinerja lembaga yaitu : viabilitas keuangan, viabilitas ekonomi, viabilitas institusi, dan viabilitas nasabah (Khandker dkk, 1995). Studi yang dilakukan oleh Raviez terhadap lima model lembaga kredit mikro di Indonesia pada tahun 1996 menyimpulkan bahwa insentif kepada nasabah dan staf pelaksana yang didesain dengan hati-hati merupakan elemen kunci dari kesuksesan lembaga. Hasil penelitian Bank Dunia terhadap 200 lembaga kredit mikro selama periode 1995-1996, ditemukan bahwa variabel-variabel yang mempengaruhi kesuksesan lembaga adalah kondisi makro ekonomi yang kondusif, perkembangan lembaga yang terkontrol, mobilisasi dana dan pengendalian biaya (Ledgerwood, 1999). Penelitian Kaluge terhadap dua model lembaga kredit mikro di Indonesia pada tahun 2001 menyimpulkan bahwa kesinambungan hidup lembaga kredit mikro sangat tergantung kepada besarnya biaya operasional dan penerimaan, dimana kedua faktor ini secara bersama-sama menentukan tingkat keuntungan. Secara rinci Kaluge mengemukakan bahwa besarnya penerimaan/revenue, besarnya biaya operasional, tingkat angsuran, tingkat bunga pinjaman dan tingkat efisiensi merupakan varibel-variabel yang mempengaruhi kinerja dan kelangsungan hidup lembaga (Kaluge, 2001). 


\section{METODE PENELITIAN DAN ANALISIS DATA}

Penelitian ini dilakukan di seluruh wilayah Kabupaten Malang yang untuk kawasan bagian Selatan diwakili oleh lembaga keuangan pedesaan di Kecamatan Kepanjen dan Tajinan, untuk wilayah bagian Utara adalah Kecamatan Lawang dan Singosari, untuk bagian Barat adalah Kecamatan Ngantang dan Karang Ploso sedangkan untuk bagian Timur adalah Kecamatan Dampit.

Unit analisis penelitian ini adalah Lembaga Pembiayaan Pedesaan berupa Koperasi Simpan Pinjam (KSP) mengingat bentuk KSP merupakan salah satu jenis lembaga keuangan pedesaan yang sangat banyak jumlahnya dan sasaran utama dari lembaga ini pada umumnya adalah kelompok ekonomi lemah dan usaha-usaha skala kecil.

Fokus kajian studi ini pada dasarnya adalah untuk mengungkap sejauh mana derajat kesinambungan lembaga keuangan pedesaan yang ada dan melakukan identifikasi mengenai variabel-variabel apa yang menentukan kesinambungan operasional lembaga yang bersangkutan. Data yang akan digali berupa data sekunder yang merupakan publikasi dari masing-masing lembaga keuangan sampel. Mempertimbangkan keterbatasan sarana, maka metode pengumpulan data yang digunakan dalam penelitian ini adalah metode survei dan pengambilan sampel dilakukan dengan menggunakan teknik incidental sampling. Variabel penelitian ini terdiri adalah kesinambungan lembaga, penerimaan, biaya operasional, tingkat angsuran, bunga pinjaman dan tingkat efisiensi. Sehubungan dengan tujuan penelitian yang ingin mengukur besarnya peranan faktor-faktor determinan kesinambungan lembaga, maka teknik analisis yang digunakan pada penelitian ini adalah Teknik Regresi dengan variabel bebas dan variabel terikat sebagai berikut:

a. Variabel terikat adalah: Kesinambungan lembaga (Y),

b. Variabel bebas adalah: Penerimaan (X1), Biaya operasional (X2), Tingkat angsuran (X3), Bunga pinjaman (X4), dan Tingkat efisiensi (X5).

\section{Batasan Variabel}

a. Kesinambungan lembaga (Y) adalah kemampuan lembaga untuk membiayai kegiatan dari pendapatan operasionalnya dalam hal ini kesinambungan lembaga diukur melalui rata-rata rasio jumlah pendapatan dengan jumlah biaya operasional per bulan selama 3 tahun

b. Penerimaan (X1) adalah jumlah rata-rata pendapatan operasional dalam rupiah per bulan selama 3 tahun yang berasal dari bunga pinjaman ditambah dengan pendapatan lain-lain

c. Biaya operasional (X2) adalah rata-rata jumlah pengeluaran dalam rupiah per bulan selama 3 tahun untuk gaji, utilitas, ATK, penyusutan dan lain-lain yang berhubungan langsung dengan kegiatan operasional

d. Tingkat angsuran (X3) adalah prosentase rata-rata penerimaan angsuran yang masuk terhadap total angsuran yang seharusnya diterima rata-rata perbulan selama 3 tahun

e. Bunga pinjaman (X4) adalah besarnya prosentase tingkat bunga pertahun yang harus dibayar oleh debitur berdasarkan ketentuan dari pihak lembaga/kreditur

f. Tingkat efisiensi (X5) adalah tingkat kesesuain pencapaian target sasaran dalam kaitannya dengan waktu, biaya dan tenaga. Dalam penelitian ini tingkat efisiensi diukur melalui ratarata rasio jumlah nasabah per petugas lembaga setiap bulan selama periode 3 tahun. 


\section{HASIL DAN PEMBAHASAN}

Berdasarkan konsep kesinambungan finansial lembaga dan teknik analisis regresi linier untuk menguji pengaruh dan variabel Operating Cost Ratio dan Return on Performing Asset, diperoleh hasil uji statistik yang secara garis besar bisa dikemukakan sebagai berikut:

a. Baik Operating Cost (Variabel biaya) maupun Return on Performing Asset (Variabel pendapatan finansial) secara statistik mempunyai pengaruh nyata terhadap tingkat Kesinambungan Finasial lembaga (Operating Self Sufficiency). Variabel biaya operasional (Operating Cost) menunjukkan hubungan negatif dan variabel pendapatan finansial ( $R e-$ turn on Performing Asset) menunjukkan hubungan yang positif. Dilihat dari derajat intensitas pengaruhnya, nampak bahwa variabel Biaya Operasional mempunyai pengaruh yang relatif lebih besar daripada variabel Pendapatan.

Operating Self Sufficiency (OSS) pada hakekatnya menujukkan kemampuan lembaga yang bersangkutan untuk membiayai kegiatan operasionalnya dari hasil kegiatan operasional. Besarnya kemampuan ditunjukkan oleh besarnya nilai OSS dimana semakin tinggi nilai OSS semakin tinggi derajat kemampuan lembaga tersebut untuk mempertahankan kesinambungan operasionalnya.

Dari seluruh KSP sampel, nampak bahwa KSP Memper Jaya dan BROM mempunyai OSS paling tinggi $(1,80)$ sedangkan KSP Setia Bakti menujukkan OSS yang paling rendah $(1,03)$.

Tabel 1: KSP Sampel menurut Ranking Operating Self-Sufficiency

\begin{tabular}{llll}
\hline No & KSP & Lokasi & OSS \\
\hline $\mathbf{1}$ & Memper Jaya & - & 1,80 \\
$\mathbf{2}$ & BROM & Kepanjen & 1,80 \\
$\mathbf{3}$ & Lawang Dana Sejahtera & Lawang & 1,61 \\
$\mathbf{4}$ & Prima Guna Dana & Kepanjen & 1,52 \\
$\mathbf{5}$ & Perak & Kepanjen & 1,47 \\
$\mathbf{6}$ & Arta Karya Mandiri & Singosari & 1,35 \\
$\mathbf{7}$ & Mustika & Kepanjen & 1,32 \\
$\mathbf{8}$ & Mitra Mandiri & Karang Ploso & 1,31 \\
$\mathbf{9}$ & Arta Jaya Sentosa & Ngantang & 1,21 \\
$\mathbf{1 0}$ & Setia Bakti Nurwahana & Tajinan & 1,15 \\
$\mathbf{1 1}$ & Mitra Usaha & Karang Ploso & 1,10 \\
$\mathbf{1 2}$ & Wahana Bakti Sentosa & Dampit & 1,10 \\
$\mathbf{1 3}$ & Agung Cipta Guna & Kebon Agung & 1,09 \\
$\mathbf{1 4}$ & Wahana Masyarakat & Ngantang & 1,06 \\
$\mathbf{1 5}$ & Setia Bakti & - & 1,03 \\
\hline
\end{tabular}

Sumber: Data primer, diolah

Dari hasil uji statistik regresi dengan variabel terikatnya adalah variabel Pendapatan $(F i$ nancial Income) dan variabel bebasnya adalah Biaya Operasional, Average Performing Asset dan Nilai Pinjaman yang diberikan/Piutang, menunjukkan bahwa dari tiga variabel bebas tersebut, walaupun nilai $\mathrm{R}^{2}$ mencapai 0,814 , ternyata hanya variabel Nilai Pinjaman yang mempunyai pengaruh dan hubungan positif yang signifikan terhadap tingkat pendapatan lembaga (Financial Income). 
Dari hasil uji statistik regresi dengan variabel terikatnya adalah Biaya Operasional (Operating Expenses) dan variabel bebasnya adalah Jumlah Anggota, Nilai Pinjaman yang diberikan/ Piutang, dan Jumlah Staff nampak bahwa dari tiga variabel bebas tersebut, hanya variabel Nilai Pinjaman yang diberikan/Piutang yang mempunyai pengaruh dan hubungan positif yang signifikan.

Dari KSP sampel, nampak bahwa KSP Wahana Masyarakat - Ngantang yang menunjukkan nilai piutang paling besar yaitu mencapai Rp 1, 19 milyar sedangkan KSP yang nilai piutangnya paling rendah adalah KSP Agung Cipta Guna di Kebon Agung.

Tabel 2: Ranking KSP Sampel Menurut Rata-rata Asset, Nilai Piutang, Pinjaman perstaf dan prosentase Piutang

\begin{tabular}{|c|c|c|c|c|c|}
\hline No & KSP & $\begin{array}{l}\text { Average } \\
\text { Performing } \\
\text { Asset (Rp } \\
000)\end{array}$ & $\begin{array}{l}\text { Nilai } \\
\text { Piutang } \\
\text { (Rp 000) }\end{array}$ & $\begin{array}{l}\text { Pinjaman } \\
\text { Per staf } \\
\text { (Rp 000) }\end{array}$ & $\begin{array}{l}\% \\
\text { Piutang thd. } \\
\text { Avg.Perf.Asset }\end{array}$ \\
\hline 1 & $\begin{array}{l}\text { Wahana } \\
\text { Masyarakat }\end{array}$ & $1.210 .511,4$ & $1.197 .640,6$ & $37.426,2$ & 98,9 \\
\hline 2 & Mitra Usaha & $924.302,0$ & $887.942,4$ & $32.886,7$ & 96,0 \\
\hline 3 & Arta Jaya Sentosa & $845.188,5$ & $831.148,0$ & $92.349,7$ & 98,3 \\
\hline 4 & Memper Jaya & $761.401,9$ & $702.079,5$ & $29.253,3$ & 92,2 \\
\hline 5 & BROM & $572.688,6$ & $510.755,9$ & $46.432,3$ & 89,2 \\
\hline 6 & Prima Guna Dana & $485.629,7$ & $481.759,7$ & $43.796,3$ & 99,2 \\
\hline 7 & Setia Bakti & $504.682,8$ & $478.002,0$ & $47.800,2$ & 94,7 \\
\hline 8 & $\begin{array}{ll}\text { Lawang } & \text { Dana } \\
\text { Sejahtera } & \end{array}$ & $430.153,3$ & $395.244,2$ & $43.916,0$ & 91,9 \\
\hline 9 & Arta Karya Mandiri & $377.054,8$ & $360.459,2$ & $36.045,9$ & 95,6 \\
\hline 10 & Mitra Mandiri & $264.777,2$ & $246.939,9$ & $35.277,1$ & 93,3 \\
\hline 11 & Perak & $113.625,3$ & $112.874,4$ & $11.287,4$ & 99,3 \\
\hline 12 & Mustika & $115.900,7$ & $100.697,0$ & $6.713,1$ & 86,8 \\
\hline 13 & $\begin{array}{l}\text { Wahana } \\
\text { Sentosa }\end{array}$ & $69.307,7$ & $64.245,2$ & $3.569,1$ & 92,6 \\
\hline 14 & $\begin{array}{l}\text { Setia } \\
\text { Nurwahana }\end{array}$ & $39.475,5$ & $37.430,3$ & $7.486,0$ & 94,8 \\
\hline 15 & Agung Cipta Guna & $17.141,5$ & $14.150,0$ & $2.021,4$ & 82,5 \\
\hline
\end{tabular}

Sumber: Data primer, diolah

Dari data di atas nampak bahwa terdapat pola hubungan yang searah antara besarnya Nilai Piutang dengan Nilai Pinjaman per Staf dimana semakin rendah Nilai Piutang menunjukkan adanya kecenderungan Nilai Pinjaman per Staf juga semakin menurun. Walaupun penurunan nilai piutang pada tabel diatas mula-mula diikuti oleh kenaikan nilai pinjaman per staf, namun dengan semakin menurunnya nilai piutang, maka nilai pinjaman per staf menunjukkan kecenderungan menurun yang lebih jelas.

Pada KSP sampel, peranan nilai piutang terhadap nilai Average Performing Asset cukup besar. Dari tabel diatas nampak bahwa prosentase nilai piutang terhadap Rata-rata performing asset pada hampir seluruh KSP besarnya lebih dari 90 persen. Apabila rata-rata nilai Performing Asset merupakan proksi dari kekayaan KSP, maka dapat disimpulkan bahwa terdapat hubungan searah antara nilai kekayaan KSP dengan nilai pinjaman per staf. Dengan demikian kesimpulan 
yang bisa dimunculkan dari fenomena diatas adalah terdapat hubungan yang searah antara besarnya Nilai Piutang, Besarnya kekayaan dan Efisiensi KSP (dengan ukuran Nilai Pinjaman per staf)

\section{Tingkat Efisiensi Lembaga}

Efisiensi lembaga antara lain bisa dilihat dari dua indikator yaitu nilai pinjaman per staf dan besarnya biaya per unit dana yang disalurkan. Dilihat dari nilai pinjaman per staf, nampak bahwa dari KSP Arta Jaya Sentosa mempunyai tingkat efisiensi paling tinggi sedangkan paling rendah adalah KSP Agung Cipta Guna. Dari indikator Cost per Unit Money Lent, nampak bahwa KSP Lawang Dana Sejahtera merupakan KSP yang paling tinggi tingkat efisiensinya.

Apabila indikator-indikator tersebut dihubungkan dengan OSS, nampak bahwa tidak terdapat pola hubungan yang jelas antara indikator efisiensi staf dan biaya peminjaman dengan OSS. Hal ini bisa dimengerti mengingat variabel yang menentukan nilai OSS adalah variabel-variabel yang dihitung dengan memasukkan nilai Average Performing Asset yang nilainya didominasi oleh nilai besarnya piutang. Dengan demikian OSS memang lebih erat hubunganya dengan nilai piutang daripada nilai efisiensi per unit pinjaman. Mengacu pada tabel di atas dimana nampak adanya hubungan antara besarnya asset dengan nilai piutang, maka OSS pada dasarnya erat kaitannya dengan besarnya kekayaan KSP dimana semakin besar kekayaan (Avrg.Performing Asset) KSP semakin besar rata-rata pinjaman per staf atau semakin efisien KSP yang bersangkutan.

Tabel 3: KSP Sampel Menurut Besarnya nilai OSS, Pinjaman per staf dan Cost per Unit Pinjaman

\begin{tabular}{|c|c|c|c|c|c|}
\hline No & KSP & Lokasi & oss & $\begin{array}{l}\text { Pinjaman } \\
\text { Per Staf } \\
\text { (Rp 000) }\end{array}$ & $\begin{array}{l}\text { Cost } \\
\text { per Unit } \\
\text { Money Lent }\end{array}$ \\
\hline 1 & Memper Jaya & - & 1,80 & $29.253,3$ & 0,537 \\
\hline 2 & BROM & Kepanjen & 1,80 & $46.432,3$ & 0,151 \\
\hline 3 & $\begin{array}{ll}\text { Lawang } & \text { Dana } \\
\text { Sejahtera } & \end{array}$ & Lawang & 1,61 & $43.916,0$ & 0,056 \\
\hline 4 & Prima Guna Dana & Kepanjen & 1,52 & $43.796,3$ & 0,112 \\
\hline 5 & Perak & Kepanjen & 1,47 & $11.287,4$ & 0,081 \\
\hline 6 & Arta Karya Mandiri & Singosari & 1,35 & $36.045,9$ & 0,046 \\
\hline 7 & Mustika & Kepanjen & 1,32 & $6.713,1$ & 0,153 \\
\hline 8 & Mitra Mandiri & $\begin{array}{l}\text { Karang } \\
\text { Ploso }\end{array}$ & 1,31 & $35.277,1$ & 0,243 \\
\hline 9 & Arta Jaya Sentosa & Ngantang & 1,21 & $92.349,7$ & 0,358 \\
\hline 10 & $\begin{array}{ll}\text { Setia } & \text { Bakti } \\
\text { Nurwahana } & \end{array}$ & Tajinan & 1,15 & $7.486,0$ & 0,172 \\
\hline 11 & Mitra Usaha & $\begin{array}{l}\text { Karang } \\
\text { Ploso }\end{array}$ & 1,10 & $32.886,7$ & 0,391 \\
\hline 12 & $\begin{array}{l}\text { Wahana } \\
\text { Sentosa }\end{array}$ & Dampit & 1,10 & $3.569,2$ & 1,105 \\
\hline 13 & Agung Cipta Guna & $\begin{array}{l}\text { Kebon } \\
\text { Agung }\end{array}$ & 1,09 & $2.021,4$ & 0,940 \\
\hline 14 & $\begin{array}{l}\text { Wahana } \\
\text { Masyarakat }\end{array}$ & Ngantang & 1,06 & $37.426,2$ & 0,332 \\
\hline 15 & Setia Bakti & - & 1,03 & $47.800,2$ & 0,680 \\
\hline
\end{tabular}

Sumber: Data primer, diolah 


\section{E. KESIMPULAN DAN REKOMENDASI}

\section{Kesimpulan}

Dari hasil uji statistik dan pembahasan dapat disimpulkan sebagai berikut :

1. Derajat kesinambungan finansial bagi lembaga pembiayaan pedesaan dipengaruhi secara nyata oleh variabel biaya operasional dan variabel pendapatan dimana tingkat pendaptan mempunyai hubungan positif sedangkan variabel biaya mempunyai hubungan yang negatif. Dari dua variabel bebas tersebut, pengaruh variabel Biaya Operasional relatif lebih besar dari pada pengaruh variabel Pendapatan.

2. Baik Tingkat Pendapatan maupun dengan Biaya Operasional mempunyai hubungan positif dan nyata Besarnya Nilai Piutang/Nilai Pinjaman.

3. Tingkat kesinambungan finansial lembaga tidak menunjukkan pola hubungan yang jelas dengan efisiensi (baik dilihat dari indikator Nilai Pinjaman per Staf maupun Biaya per unit pinjaman/Cost per Unit Money Lent).

4. Dibandingkan dengan indikator Cost per Unit Money Lent, Nilai pinjaman per staf menunjukkan pola hubungan yang lebih jelas dengan besarnya Average Performing Asset dari (Sedangkan Cost per unit Money Lent tidak menunjukkan pola hubungan yang jelas dengan Average Performing Asset). Disamping itu nilai Average Performing Asset didominasi oleh Nilai Piutang. Dengan demikian dapat disimpulkan bahwa semakin besar nilai Average Performing Asset, semakin besar Nilai Piutang dan semakin efisien lembaga KSP.

\section{Rekomendasi}

1. Besarnya peranan Nilai Piutang/Pinjaman terhadap tingkat kelangsungan finansial lembaga menunjukkan bahwa dalam rangka menjaga kelangsungan hidup lembaga pembiayaan pedesaan khususnya dalam bentuk KSP, strategi yang harus ditempuh oleh pengelola adalah melakukan upaya meningkatkan volume pinjaman yang bisa diberikan. Dari pihak nasabah, meningkatnya volume pinjaman jelas sangat membantu peningkatan kapasitas bisnis yang dilakukannya. Untuk itu pemerintah perlu melakukan kebijakan yang bisa mendukung peningkatan modal KSP melalui program mengakses pinjaman lunak mengingat rendahnya kemampuan KSP menggalang modal dari simpanan anggota.

2. Peningkatan jumlah pinjaman oleh KSP mempunyai pengaruh terhadap efisiensi khususnya efisiensi penggunaan tenaga kerja. Sehubungan dengan itu selain diperlukan program-program pelatihan yang memadai bagi peningkatan kinerja petugas lapangan, juga semakin diperlukan sistem kontrol/monitoring yang efektif terhadap operasionalsasi kegiatan petugas lapang. Disini peranan pihak manajer dalam mengorganisir jalannya orgaisasi sangat menentukan

3. Salah satu dampak negatif dari strategi mengoptimalkan staf lapang untuk meningkatkan Nilai Piutangnya adalah adanya kecenderungan sasaran semakin mengarah pada nasabah golongan ekonomi kuat. Hal ini akan menurunkan peluang kelompok usaha gurem untuk mengakses kredit dari lembaga keuangan pedesaan. Untuk itu pemerintah perlu mempertimbangkan adanya insentif yang efektif bagi lembaga-lembaga pembiayaan pedesaan yang melayani usaha-usaha mikro. 


\section{DAFTAR PUSTAKA}

Adams, D. W ( 1984 ), Are the Arguments for Cheap Agricultural Credit Sound?, Undermining Rural Development With Cheap Credit, Westview Press, London

Adams, D. W., D. H. Graham, et al ( 1984 ), Overview of Relationship Between Politics and Finance, Undermining Rural Development With Cheap Credit, Westview Press, London

Ashar, Khusnul (2002), Pemberdayaan Ekonomi Perempuan Dari Keluarga Kurang Mampu Dengan Model Grameen Bank di Jawa Timur : Sebuah Pengalaman Lapangan, makalah dipresentasikan pada Seminar Nasional Isu Kebijakan Gender Dalam Pembangunan, oleh Kantor Menko Bidang Kesra di Surakarta, 11 Juli 2002.

Bank Dunia ( 1975 ), Agricultural Credit : Sector Policy Paper, The World Bank, Washington, D.C.

Braverman, Avishay dan J.Luis Guasch ( 1989 ), Rural Credit in LDCs : Issues and Evidence, Journal of Economic Developmen $14: 7$ - 34

Cho, Yoonje dan Dinanath Khatkhate ( 1989 ), Lessons of Financial Liberalization in Asia: A Comparative Study, World Bank Discussion Paper 50, The World Bank, Washington D.C.

ECD ( 2000 ), Microfinace, Methodological Considerations, The European Commision Development, Second edition

Garson, J ( 1998 ), Microfinace and Anti Poverty Strategy,_UNCDF.

Gibbons, David ( 2001), Poverty Reduction in Indonesia Through Scaling-Up Grameen Bank-type Microofinance paper dipresentasikan untuk AusAID-Australia

Gonzales-Vega, C ( 1976 ), On the Iron Law of Interest Rate Restrictions.Agricultural Credit Policies in Costa Rica and in Other Less Developed Countries, Economics.

Gulli, H ( 1998 ), Microfinance and Poverty : Questioning the Convensional Wisdom, Inter American Development Bank

Hoff, Karla dan Joseph E. Stiglitz ( 1990 ), Introduction : Imperfect Information and Rural Credit Market - Puzzles and Policy Perpectives, The World Bank Economic Review 4 (3).

Holt, Sharon L dan Helena Ribe( 1991), Developing Financial Institutions for the Poor and Reducing Barriers to Access for Women, World Bank Discussion Paper 117, The World Bank, Washington D.C.

Huppi, Monika dan Feder, Gershon ( 1990 ), Role of Groups and Credit Cooperatives in Rural Lending, World Bank Research Observer 5

Khandker, Shahidur et al ( 1995 ), Grameen Bank, Performance and Sustainability, World Bank Discussion Papers 306, The World Bank, Washington D.C.

Ledgerwood, Joana ( 1999 ), Sustainable Bangking With The Poor : Microfinance Handbook, An Institutional and Fiancial Perspective, The World Bank, Washington D.C. 